\title{
EVALUASI KINERJA KEUANGAN PEMERINTAH DALAM "PROGRAM DUKUNGAN MANAJEMEN DAN TUGAS TEKNIS LAINNYA KEMENTERIAN AGAMA" DENGAN MENGGUNAKAN METODE VALUE FOR MONEY PADA KANTOR KEMENTERIAN AGAMA PROVINSI SULAWESI UTARA
}

\author{
Rismawaty Nainu ${ }^{1}$, Jullie J. Sondakh ${ }^{2}$, Novi S. Budiarso ${ }^{3}$ \\ ${ }^{1,2,3}$ Fakultas Ekonomi dan Bisnis, Jurusan Akuntansi, Universitas Sam Ratulangi, Jl.Kampus Bahu, Manado \\ 95115, Indonesia \\ E-mail: nainurisma@gmail.com
}

\begin{abstract}
Value for money in the context of regional autonomy is a bridge to deliver local governments to achieve good governance. To support the implementation of public funds management (public money), which based on the concept of value for money, it is necessary to have good regional financial management system and local budget. The purpose of this study is to know how the government's performance in management support programs and other technical task implementers if using the method of value for money. The method used in this research is qualitative descriptive method that quantitative. The results showed that the calculation of economic ratios showed less than $90 \%$ which means quite economical in the standard value for money. Thus the Office of the Ministry of Religious Affairs of North Sulawesi Province is economical in the expenditure of its spending budget. The efficiency ratio shows less than $100 \%$ result which means quite efficient in standard value for money. Thus the Office of the Ministry of Religious Affairs of North Sulawesi Province quite efficient in the expenditure of spending budget. The effectiveness ratio shows the result is above 100\% (> 100\%) so it shows the Ministry of Religious Affairs Office of North Sulawesi Province is very effective in expenditure budget utilization.
\end{abstract}

Keywords: Financial Performance, Value for Money Method

\section{PENDAHULUAN}

Upaya menyelenggarakan pemerintahan yang bersih dan bebas Kolusi, Korupsi dan Nepotisme (KKN), sekaligus sebagai pemenuhan atas tuntutan publik atas kinerja pemerintah sesuai peraturan menteri dalam negeri nomor 73 tahun 2009 tentang tata cara pelaksanaan evaluasi kinerja penyelenggaraaan pemerintah daerah. Pengelolaan keuangan tidak dapat dilepaskan dari keberadaan Undang-Undang Nomor 17 Tahun 2003 tentang Keuangan Negara, Undang-Undang Nomor 1 Tahun 2004 tentang Perbendaharaan Negara dan UndangUndang Nomor 15 Tahun 2004 tentang Pemeriksaan Pengelolaan dan Tanggung Jawab Keuangan Negara. Dengan terbitnya Undang-Undang Nomor 32 Tahun 2004 dan UndangUndang Nomor 33 Tahun 2004 maka berbagai prinsip dasar yang ada dalam Undang-Undang Keuangan Negara, Undang-Undang Perbendaharaan Negara dan Undang-Undang Pemeriksaan Pengelolaan dan Tanggung Jawab Keuangan Negara kembali dipertegas dan menjadi acuan dalam pengalihan keuangan. Pengelolaan Keuangan Pemerintah meliputi tiga tahapan yaitu : Perencanaan dan Penganggaran, Pelaksanaan serta Pertanggungjawaban.

Pengukuran kinerja yang digunakan oleh pemerintah, adalah pengukuran kinerja yang tradisional. Metode ini memusatkan pada aspek keuangan saja namun dengan menggunakan metode value for money, capaian tidaklah hanya diukur dari aspek keuangan saja, tetapi juga dari aspek non keuangan. Tuntutan akan kualitas dan profesionalisme sektor publik dapat dinilai dengan konsep value for money (Nilai daripada uang) dalam menjalankan aktivitasnya. Value for money merupakan konsep pengelolaan organisasi sektor publik yang mendasarkan pada tiga elemen utama, yaitu ekonomi, efisiensi, dan efektivitas. Selain itu, 
tuntutan yang lain adalah perlunya akuntabilitas publik dan privatisasi terhadap perusahaanperusahaan milik publik untuk menciptakan good publik and corporate governance (Mardiasmo, 2010:27). Model value for money atau yang dikenal dengan model 3E (ekonomi, efisiensi, dan efektivitas), mengukur dengan analisis varian yakni membandingkan antara input dan output yang direncanakan dengan input dan output aktualnya. Ekonomi diukur melalui rasio antara masukan aktual dengan masukan rencana. Efisiensi diukur melalui rasio efisiensi aktual dengan rasio efisiensi yang direncanakan. Efektivitas diukur dengan membandingkan keluaran realisasian (aktual) dengan keluaran menurut rencana (Mardiasmo, 2010 :27). Value for money dalam konteks otonomi daerah merupakan jembatan untuk menghantarkan pemerintah daerah mencapai good governance. Untuk mendukung dilakukannya pengelolaan dana publik (publik money) yang mendasarkan konsep value for money, maka diperlukan sistem pengelolaan keuangan daerah dan anggaran daerah yang baik.

Sistem ini mengukur keberhasilan maupun kegagalan program dan kegiatan dengan melakukan evaluasi tingkat capaian kinerja yang dapat direalisasikan sebagai imbalan atas dihabiskannya anggaran dan adanya umpan balik atas kegagalan pencapaian guna perbaikan strategi di masa yang akan datang. Maka dengan ini tugas dan tanggung jawab yang harus dijalankan Pemerintah, dalam hal ini Kantor Wilayah Kementerian Agama Provinsi Sulawesi Utara semakin banyak. Termasuk kesiapan dalam menghadapi evaluasi atas kinerja yang telah dilaksanakan. Salah satu hal yang dapat dijadikan alat untuk menilai pertanggungjawaban suatu instansi Pemerintah adalah dengan melihat kinerja keuangan Kementerian melalui perhitungan dan analisis terhadap pencapai target dan realisasi dari penerimaan dan pengeluaran atas Anggaran Pendapatan dan Belanja, baik dari sisi input, output, impact, dan benefit-nya. Untuk itu Kantor Wilayah Kementerian Agama Provinsi Sulawesi Utara diharapkan agar memperhatikan Value For Money.

Berdasarkan latar belakang yang diuraikan di atas maka dapat diidentifikasi masalah dalam penelitian ini yaitu Evaluasi Kinerja Keuangan Pemerintah dalam "Program Dukungan Manajemen dan Pelaksanaan Tugas Teknis Lainnya Kementerian Agama" dengan menggunakan Metode Value for Money Pada Kantor Wilayah Kementerian Agama Provinsi Sulawesi Utara.

\section{TINJAUAN PUSTAKA}

\subsection{Pengertian Akuntansi}

Menurut Ikatan Akuntan Indonesia (2017) Akuntansi merupakan kumpulan konsep dan teknik yang digunakan untuk mengukur dan melaporkan informasi keuangan dalam suatu unit usaha ekonomi. Akuntansi adalah suatu aktivitas jasa yang terdiri dari mencatat, mengklasifikasikan, dan melaporkan kejadian atau transaksi ekonomi yang akhirnya akan menghasilkan suatu informasi keuangan yang dibutuhkan oleh pihak-pihak tertentu untuk pengambilan keputusan. (Sujarweni, 2015:1)

Menurut Winston Pontoh (2013:2) akuntansi pada dasarnya akan menghasilkan informasi dari sebuah sistem akuntansi yang ada di dalam sebuah entitas atau organisasi bisnis yang disebut dengan informasi akuntansi yang akan dimanfaatkan oleh pengguna seperti masyarakat umum, masyarakat intelektual (termasuk didalamnya mahasiswa atau peneliti) dan para pengambil keputusan bisnis dalam organisasi. Pengertian akuntansi menurut Pura (2013:4) adalah seperangkat pengetahuan yang mempelajari perekayasaan dalam penyediaan jasa, yang berupa informasi keuangan dari satu unit organisasi dan cara penyampaian (pelaporan) informasi tersenut kepada pihak berkepentingan untuk dijadikan dasar pengambilan keputusan ekonomi. 


\subsection{Akuntansi Sektor Publik}

Akuntansi Sektor Publik didefinisikan sebagai mekanisme teknik dan analisis akuntansi yang diterapkan pada pengelolaan dana masyarakat di lembaga-lembaga tinggi Negara dan departemen-departemen di bawahnya, pemerintah daerah, BUMN, BUMD, LSM, dan yayasan sosial, maupun proyek-proyek kerjasama sektor publik dan swasta. Mardiasmo (2012:37) dalam pengertian umum yang khususnya bagi dunia akuntansi dinegara-negara maju organisasi sektor publik terbagi dalam tiga kelompok besar yaitu :

1. Pemerintah Pusat, yang terdiri dari departeman dan badan-badan di bawah pemerintah eksekutif.

2. Industri atau perusahaan untuk kepentingan publik atau masyarakat luas.

3. Pemerintah Daerah, bagi tingkat propinsi maupun kabupaten/kota.

Sektor publik adalah semua yang berhubungan dengan kepentingan publik dan tentang penyediaan barang dan jasa yang ditujukan untuk publik, dibayarkan melalui pajak dan pendapatan negara lainnya yang sudah diatur dalam hukum.

\subsection{Akuntansi Pemerintahan}

Menurut Halim (2013:1) bahwa Akuntansi keuangan (Pemerintahan) daerah di Indonesia merupakan salah satu bidang dalam akuntansi sektor publik yang mendapat perhatian besar dari berbagai pihak semenjak reformasi tahun 1998. Menurut Mursyidi (2012:1), Akuntansi Pemerintahan (governmental accounting) banyak menyatakan teminologi lama dan bergeser ke istilah akuntansi sektor publik. Akuntansi pemerintahan adalah mekanisme akuntansi yang memproses transaksi keuangan yang berkaitan dengan pengelolaan keuangan negara baik tingkat pusat maupun tingkat daerah.

Nordiawan et.al (2012:4), menyatakan bahwa akuntansi pemerintahan mengkhususkan dalam pencatatan dan pelaporan transaksi-transaksi yang terjadi di badan pemerintah. Akuntan pemerintah menyediakan laporan akuntansi tentang aspek kepengurusan dari administrasi keuangan negara. Selain itu, bidang ini meliputi pengendalian atas pengeluaran melalui anggaran negara, termasuk kesesuaiannya dengan undang-undang yang berlaku.

\subsection{Standar Akuntansi Pemerintahan}

Menurut PP No. 71 Tahun 2010 Standar Akuntansi Pemerintahan merupakan persyaratan yang mempunyai kekuatan hukum dalam upaya meningkatkan kualitas laporan keuangan yang diharapkan dapat terciptanya transparansi, partisipasi, dan akuntanbilitas pengelolaan keuangan negara guna mewujudkan pemerintahan yang baik (good governance). Mahmudi (2011:271), Standar akuntansi pemerintahan adalah prinsip-prinsip akuntansi yang diterapkan dalam menyusun dan menyajikan laporan keuangan pemerintah. Berikut adalah manfaat standar akuntansi pemerintahan: (1) standar akuntansi digunakan oleh akuntan keuangan di pemerintahan sebagai pedoman dalam penyusunan dan penyajian laporan keuangan pemerintahan; (2) standar akuntansi digunakan oleh auditor sebagai kriteria audit untuk menentukan apakah laporan keuangan yang disajikan sudah sesuai dengan standar akuntansi yang mengaturnya; (3) standar akuntansi digunakan oleh pengguna laporan keuangan untuk memahami laporan keuangan dan menghindari kesalahan dalam menginterpretasikan informasi dalam laporan keuangan; (4) standar akuntansi diperlukan untuk meningkatkan kualitas laporan keuangan yaitu meningkatkan konsistensi, daya banding, keterpahaman, relevansi, dan keandalan laporan keuangan; dan (5) standar akuntansi menjadi acuan dalam penyusunan sistem akuntansi sebab keluaran sistem akuntansi harus sesuai dengan standar akuntansi.

\subsection{Konsep Kinerja}

Kinerja/Prestasi kerja adalah tingkat pelaksanaan tugas yang dapat dicapai oleh seseorang, unit atau divisi dengan menggunakan kemampuan yang ada dan batasan-batasan 
yang telah ditetapkan untuk mencapai tujuan organisasi atau perusahaan (Samsudin, 2011:159).

\subsubsection{Penilaian Kinerja}

Pengukuran kinerja digunakan sebagai dasar untuk melakukan penilaian kinerja yaitu untuk menilai sukses atau tidaknya suatu organisasi, program, atau kegiatan. Mulyadi (2014:416) menjelaskan penilaian kinerja adalah penentuan secara periodik efektivitas operasional suatu organisasi, bagian organisasi, dan karyawannya berdasarkan sasaran, standar, dan kriteria yang telah ditetapkan sebelumnya. Penilaian kinerja merupakan suatu cara manajemen dalam menilai keefektivitasan suatu kegiatan yang dilakukan berdasarkan pada sasaran, standar, dan kriteria yang telah ditetapkan dalam sebuah anggaran

\subsubsection{Tujuan Penilaian Kinerja Keuangan}

Tujuan penilaian kinerja keuangan perusahaan menurut Munawir (2010:31) adalah sebagai berikut:

1. Untuk mengetahui tingkat likuiditas, yaitu kemampuan perusahaan untuk memperoleh kewajiban keuangannya yang harus segera dipenuhi atau kemampuan perusahaan untuk memenuhi keuangannya pada saat ditagih.

2. Untuk mengetahui tingkat solvabilitas, yaitu kemampuan perusahaan untuk memenuhi kewajiban keuangannya apabila perusahaan tersebut dilikuidasi baik kewajiban keuangan jangka pendek maupun jangka panjang.

3. Untuk mengetahui tingkat rentabilitas atau profitabilitas, yaitu menunjukkan kemampuan perusahaan untuk menghasilkan laba selama periode tertentu.

4. Untuk mengetahui tingkat stabilitas usaha, yaitu kemampuan perusahaan untuk melakukan usahanya dengan stabil, yang diukur dengan mempertimbangkan kemampuan perusahaan untuk membayar beban bunga atas hutang-hutangnya termasuk membayar kembali pokok hutangnya tepat pada waktunya serta kemampuan membayar deviden secara teratur kepada para pemegang saham tanpa mengalami hambatan atau krisis keuangan..

\subsubsection{Manfaat Penilaian Kinerja Keuangan}

Manfaat yang didapat dari penilaian kinerja keuangan perusahaan adalah sebagai berikut:

1. Untuk mengukur prestasi yang dicapai oleh suatu organisasi dalam suatu periode tertentu yang mencerminkan tingkat keberhasilan pelaksanaan kegiatannya.

2. Selain digunakan untuk melihat kinerja organisasi secara keseluruhan, maka pengukuran kinerja juga dapat digunakan untuk menilai kontribusi suatu bagian dalam pencapaian tujuan perusahaan secara keseluruhan.

3. Dapat digunakan sebagai dasar penentuan strategi perusahaan untuk masa yang akan datang.

4. Memberi petunjuk dalam pembuatan keputusan dan kegiatan organisasi pada umumnya dan divisi atau bagian organisasi pada khususnya.

5. Sebagai dasar penentuan kebijaksanaan penanaman modal agar dapat mningkatkan efisiensi dan produktivitas perusahaan.

\subsection{Kinerja Keuangan Kementerian/Lembaga}

Kementerian merupakan lembaga pemerintah Indonesia yang membidangi urusan tertentu dalam pemerintah. Kementerian berkedudukan di Jakarta (ibukota negara) dan bertanggungjawab langsung kepada presiden serta berada dibawah presiden. Selain itu lembaga pemerintahan kementerian juga diatur oleh Peraturan Presiden Nomor 7 Tahun 2015 tentang Organisasi Kementerian Negara serta Undang-undang Nomor 39 Tahun 2008 tentang Kementerian Negara.

Adapun beberapa hal yang berkaitan dengan Kementerian/Lembaga yaitu Rencana Kerja dan Anggaran Kementerian Negara/Lembaga (RKA-K/L) adalah dokumen rencana 
keuangan tahunan Kementerian/Lembaga yang disusun menurut bagian anggaran (PMK Nomor 7/PMK.02/2014). RKAKL dibuat setiap tahun untuk 2 tahun ke depan

\subsection{Value for Money}

Value for money merupakan konsep pengelolaan organisasi sektor publik yang mendasarkan pada tiga elemen utama, yaitu: ekonomi, efisiensi, dan efektivitas. Value for money merupakan inti pengukuran kinerja pada organisasi pemerintah. Value for money menurut Mardiasmo (2010:130) merupakan konsep pengelolaan organisasi sektor publik yang mendasarkan pada tiga elemen utama, yaitu ekonomis, efisiensi, dan efektifitas. Ekonomis: pemerolehan input dengan kualitas dan kuantitas tertentu pada harga yang terendah. Ekonomis merupakan perbandingan input dengan input value yang dinyatakan dalam satuan moneter. Efisiensi: pencapaian output yang maksimum dengan input tertentu untuk penggunaan input yang terendah untuk mencapai output tertentu. Efisiensi merupakan perbandingan output/input yang dikaitkan dengan standar kinerja atau target yang telah ditetapkan. Efektifitas: tingkat pencapaian hasil program dengan target yang ditetapkan. Secara sederhana efektifitas merupakan perbandingan outcome dengan output.

\subsubsection{Elemen-elemen Value for Money}

1. Ekonomi merupakan pemerolehan input dengan kualitas dan kuantitas tertentu pada harga yang terendah. Ekonomi merupakan perbandingan input dengan input value yang dinyatakan dalam satuan moneter. Ekonomi terkait dengan sejauh mana organisasi organisasi sektor publik dapat meminimalisir input resources yang digunakan yaitu dengan menghindari pengeluaran yang boros dan tidak produktif.

2. Efisiensi merupakan pencapaian output yang maksimum dengan input tertentu atau penggunaan input yang terendah untuk mencapai output tertentu. Efisiensi merupakan perbandingan output atau input yang dikaitkan dengan standar kinerja atau target yang telah ditetapkan. Suatu organisasi, program, atau kegiatan dikatakan efisiensi apabila mampu menghasilkan output tertentu dengan input serendah-rendahnya, atau dengan input tertentu mampu menghasilkan output sebesar-besarnya (spending well).

3. Efektivitas merupakan tingkat pencapaian hasil program dengan target yang ditetapkan. Secara sederhana efektivitas merupakan perbandingan outcome dengan output. Efektivitas merupakan hubungan antara output dengan tujuan. Semakin besar kontribusi output terhadap pencapaian tujuan, maka semakin efektif organisasi, program atau kegiatan.

\section{METODE PENELITIAN}

\subsection{Jenis \& Sumber Data}

Jenis Penelitian yang digunakan adalah jenis penelitian yang bersifat studi deskriptif yaitu penelitian yang dilakukan untuk mengetahui atau mengevaluasi kinerja keuangan kementerian agama dalam "program dukungan manajemen dan tugas teknis lainnya" dengan menggunakan metode value for money.

Dalam penelitian ini sumber data yang digunakan adalah data primer, yaitu hasil wawancara berupa tanya jawab langsung dengan Pejabat/Pegawai bagian Keuangan dan Perencanaan. Dan data sekunder, yaitu sejarah singkat Kantor Kementerian Agama Provinsi Sulawesi Utara dan struktur organisasi Kantor Kementerian Agama Provinsi Sulawesi Uatara. .

\subsection{Metode Analisis Data}

Metode pengumpulan data yang digunakan dalam penelitian ini adalah dokumentasi. Dokumentasi adalah suatu metode pengumpulan data dengan cara mengumpulkan dokumen yang berkaitan dengan penelitian yang dilakukan. Data yang didapat dari metode ini adalah data laporan keuangan dari Program "Dukungan Manajemen dan Tugas Teknis Lainnya" Kantor Kementerian Agama Provinsi Sulawesi Utara. Analisis data dalam penelitian ini adalah analisis data kualitatif yang di kuantitatifkan yaitu value for money dengan mengukur 
kinerja keuangan pemerintah dalam program dukungan manajemen dan pelaksana tugas teknis lainnya berdasarkan tiga elemen ekonomi, efisiensi, dan efektivitas dengan menggunakan data anggaran dari tahun 2014 sampai 2016

\section{HASIL PENELITIAN DAN PEMBAHASAN}

\subsection{Hasil Penelitian}

Berdasarkan hasil penelitian pada Kantor Kementerian Agama Provinsi Sulawesi Utara terdapat Program Dukungan Manajemen dan Tugas Teknis Lainnya. Program tersebut dilaksanakan atau terurai dalam/melalui beberapa kegiatan diantaranya: Pembinaan Administrasi Hukum dan Kerjasama Lembaga Negara (KLN), Pembinaan Administrasi Kepegawaian, Pembinaan Administrasi Keuangan dan Barang Milik Negara (BMN), Pembinaan Administrasi Organisasi dan Tata Laksana, Pembinaan Administrasi Perencanaan, dan Pembinaan Administrasi Umum.

Suatu organisasi sektor publik memerlukan adanya pengukuran kinerja untuk membantu manajer publik menilai pencapaian suatu strategi. Pengukuran kinerja pada organisasi sektor publik tidak hanya berdasarkan pada ukuran finansial saja tetapi juga pada ukuran non-finansial karena tujuan utama organisasi ini bukan memperoleh laba melainkan untuk meningkatkan kesejahteraan masyarakat. Kinerja organisasi sektor publik yang bersifat multidimensional menyebabkan tidak ada indikator tunggal yang dapat digunakan dalam pengukuran kinerja. Selain itu, output yang dihasilkan oleh organisasi sektor publik umumnya bersifat intangible, sehingga perlu adanya ukuran non-finansial yang dapat mencerminkan besarnya output yang dihasilkan. Tabel 4.1 akan menguraikan laporan realisasi anggaran Kantor Kementerian Agama Provinsi Sulawesi Utara pada Program Dukungan Manajemen dan Tugas Teknis Lainnya.

Tabel 4.1. Laporan Realisasi Anggaran Program Dukungan Manajemen dan Tugas Teknis Lainnya Kantor Kementerian Agama Provinsi Sulawesi Utara

\begin{tabular}{|c|c|c|c|}
\hline Tahun & Pengeluaran belanja & $\begin{array}{l}\text { Anggaran Belanja } \\
\text { (Rp) }\end{array}$ & $\begin{array}{c}\text { Realisasi Anggaran } \\
\text { (Rp) }\end{array}$ \\
\hline 2014 & - Pengeluaran Belanja & 14.933 .721 .000 & 14.356 .130 .733 \\
\hline 2015 & - Pengeluaran Belanja & 24.360 .225 .000 & 19.552 .684 .870 \\
\hline 2016 & - Pengeluaran Belanja & 15.898 .401 .000 & 14.190 .964 .552 \\
\hline & $\begin{array}{c}\text { Pengeluaran Program } \\
\text { (Rp) }\end{array}$ & \multicolumn{2}{|l|}{$\begin{array}{l}\text { Dana APBN } \\
(\text { Rp) }\end{array}$} \\
\hline 2014 & 10.788 .704 .783 & \multicolumn{2}{|l|}{11.287 .790 .000} \\
\hline 2015 & 13.984 .690 .124 & \multicolumn{2}{|l|}{18.065 .642 .000} \\
\hline 2016 & 12.482 .481 .352 & \multicolumn{2}{|l|}{13.630 .701 .000} \\
\hline & Pengeluaran belanja & $\begin{array}{l}\text { Anggaran Belanja } \\
(\mathbf{R p})\end{array}$ & $\begin{array}{c}\text { Realisasi Anggaran } \\
\text { (Rp) }\end{array}$ \\
\hline 2014 & $\begin{array}{l}\text { Pelayanan } \\
\text { Pemerintah }\end{array}$ & 184.500 .000 & 184.500 .000 \\
\hline 2015 & $\begin{array}{l}\text { Pelayanan } \\
\text { Pemerintah }\end{array}$ & 312.983 .000 & 312.980 .000 \\
\hline 2016 & $\begin{array}{ll}\text { Pelayanan } & \text { Keagamaan } \\
\text { Pemerintah } & \end{array}$ & 5.230 .000 & 5.196 .200 \\
\hline
\end{tabular}

Sumber : Laporan Realisasi Anggaran Program Manajemen dan Tugas Teknis Lainnya Kantor Wilayah Kementerian Agama Provinsi Sulawesi Utara. 
Berdasarkan tabel 4.1 dapat dilihat bahwa anggaran pengeluaran belanja tahun 2014 sebesar Rp 14.933.721.000 dan teralisasi sebesar Rp 14.356.130.733. Tahun 2015 dianggarakan sebesar Rp 24.360.225.000 dan terealisasi sebesar Rp 19.552.684.870. serta tahun 2016 dianggarakan sebesar Rp 15.898.401.000 dan terealisasi sebesar 14.190.964.552.

Pengeluaran Program 2014 sebesar Rp 10.788.704.783 dan dana APBN sebesar Rp 11.287.790.000. Tahun 2015 pengeluaran program sebesar $\mathrm{Rp} 13.984 .690 .124$ dan dana APBN sebesar Rp 18.065.642.000. serta tahun 2016 pengeluaran institusi sebesar Rp 12.482.481.352 dan dana APBN sebesar 13.630.701.000

Pelayanan umum tahun 2014 dianggarkan sebesar Rp 184.500 .000 dan teralisasi sebesar Rp 184.000.000. Tahun 2015 dianggarakan sebesar Rp 312.983.000 dan terealisasi sebesar Rp 312.980.000. serta tahun 2016 dianggarakan sebesar Rp 5.230.000 dan terealisasi sebesar 5.196.200.

\subsection{Pembahasan}

\section{1) Rasio Ekonomi}

Tabel 4.2. Rasio Ekonomi Kinerja Kantor Kementerian Agama Provinsi Sulawesi Utara

\begin{tabular}{|c|c|c|c|}
\hline Tahun & $\begin{array}{c}\text { Biaya Input } \\
\text { (Rp) }\end{array}$ & $\begin{array}{c}\text { Input } \\
\text { (Rp) }\end{array}$ & $\begin{array}{c}\text { Rasio } \\
\text { Ekonomis (\%) }\end{array}$ \\
\hline 2014 & 14.933 .721 .000 & 14.356 .130 .733 & 96,13 \\
\hline 2015 & 24.360 .225 .000 & 19.552 .684 .870 & 80,26 \\
\hline 2016 & 15.898 .401 .000 & 14.190 .964 .552 & 89,26 \\
\hline
\end{tabular}

Sumber : Data Olahan 2017

Berdasarkan Tabel 4.2 menunjukan bahwa tingkat ekonomis Kantor Kementerian Agama Provinsi Sulawesi Utara pada tahun 2014 adalah sebesar 96,13\%. Kemudian pada tahun 2015 tingkat ekonomis menurun menjadi 80,26\% dan tahun 2016 tingkat ekonomis kembali meningkat menjadi $89,26 \%$

Demikian dapat dikatakan bahwa hasil perhitungan rasio ekonomis sebesar 96,13\%, $80,26 \%$ dan $89,26 \%$ menunjukkan hasil kurang dari $100 \%$ yang berarti ekonomis dalam standar value for money. Dengan demikian tidak terjadi pemborosan dana anggaran belanja. Pada tahun 2014 rasio ekonomis sebesar 96,13\% namun berada dibawah $100 \%(<100 \%)$ sehingga menunjukan selama tiga tahun Kantor Wilayah Kementerian Agama Provinsi Sulawesi Utara mengalami peningkatan dalam pemanfaatan anggaran belanjanya.

Hal ini menunjukkan bahwa tingkat ekonomi untuk kinerja pemerintah dalam "Program Dukungan Manajemen dan Pelaksanaan Tugas Teknis Lainnya Kementerian Agama" pada Kantor Wilayah Kementerian Agama Provinsi Sulawesi Utara cukup ekonomis karena Kantor Wilayah Kementerian Agama Provinsi Sulawesi Utara tidak hanya mementingkan internal instansi tetapi juga mementingkan eksternal instansi dapat dilihat juga dari tahun ke tahun dana yang dikeluarkan untuk program meningkat hal ini menunjukkan bahwa adanya perhatian kementerian agama kepada masyarakat.

2) Rasio Efisiensi

Tabel 4.3. Rasio Efisisensi Kinerja Kantor Kementerian Agama Provinsi Sulawesi Utara

\begin{tabular}{|l|c|c|c|}
\hline Tahun & $\begin{array}{c}\text { Output } \\
(\mathbf{R p})\end{array}$ & $\begin{array}{c}\text { Input } \\
(\mathbf{R p})\end{array}$ & $\begin{array}{c}\text { Rasio Efisiensi } \\
(\mathbf{\%})\end{array}$ \\
\hline 2014 & 10.788 .704 .783 & 11.287 .790 .000 & 95,57 \\
\hline 2015 & 13.984 .690 .124 & 18.065 .642 .000 & 77,41 \\
\hline 2016 & 12.482 .481 .352 & 13.630 .701 .000 & 91,57 \\
\hline
\end{tabular}

Sumber : Data Olahan 2017 
Berdasarkan Tabel 4.3 menunjukan bahwa tingkat Efisiensi Kantor Wilayah Kementerian Agama Provinsi Sulawesi Utara pada tahun 2014 adalah sebesar 95,57\%. Kemudian pada tahun 2015 tingkat efisiensi menurun menjadi 77,41\% dan tahun 2016 tingkat efisiensi kembali meningkat menjadi $91.57 \%$

Hasil perhitungan rasio efisiensi sebesar $95,57 \%, 77,41 \%$ dan $91.57 \%$ menunjukan hasil kurang dari $100 \%$ yang berarti kurang efesien dalam standar value for money. Dengan demikian tidak terjadi pemborosan dana anggaran belanja, Rasio Efisisensi mengalami peningkatan, namun peningkatan yang terjadi membuat rasio efisiensi berada dibawah $100 \%$ $(<100 \%)$ sehingga menunjukan selama tiga tahun Kantor Kementerian Agama Provinsi Sulawesi Utara kurang efesien dalam pemanfaatan anggaran belanjanya.

Hal ini berarti Kantor Kementerian Agama Provinsi Sulawesi Utara dapat meminimalisir biaya dan memaksimalkan pendapatan serta dalam menggunakan hasil kerja dicapai dengan penggunaan sumber daya dan dana yang serendah-rendahnya.

\section{3) Rasio Efektivitas}

Tabel 4.4. Rasio Efektifitas Kinerja Kantor Kementerian Agama Provinsi Sulawesi Utara

\begin{tabular}{|l|c|c|c|}
\hline Tahun & $\begin{array}{c}\text { Outcomes } \\
(\mathbf{R p})\end{array}$ & $\begin{array}{c}\text { Output } \\
(\mathbf{R p})\end{array}$ & $\begin{array}{c}\text { Rasio Efektif } \\
(\mathbf{\%})\end{array}$ \\
\hline 2014 & 184.500 .000 & 184.500 .000 & 100 \\
\hline 2015 & 312.983 .000 & 312.733 .000 & 100.07 \\
\hline 2016 & 5.230 .000 & 5.196 .200 & 102.65 \\
\hline
\end{tabular}

Sumber : Data Olahan 2017

Berdasaarkan Tabel 4.4 menunjukan bahwa tingkat Efektifitas Kantor Kementerian Agama Provinsi Sulawesi Utara pada tahun 2014 adalah sebesar 100\%. Kemudian pada tahun 2015 tingkat ekonomis meningkat menjadi 100.07\% dan tahun 2016 tingkat efektifitas meningkat lagi menjadi $102.65 \%$

Rasio efektifitas mengalami peningkatan, namun peningkatan yang terjadi membuat rasio ekonomis berada diatas $100 \%(>100 \%)$ sehingga menunjukan selama tiga tahun Kantor Kementerian Agama Provinsi Sulawesi Utara sangat efektif dalam pemanfaatan anggaran belanjanya. Pada rasio efektivitas selama tiga tahun sudah dapat dikatakan sangat efektif, karena rasio berada di atas $100 \%$ (>100\%) atau sudah memenuhi standar.

Rasio efektivitas mengalami peningkatan tiga tahun. Hal ini menunjukan bahwa Kantor Wilayah Kementerian Agama Provinsi Sulawesi Utara sudah berhasil dalam menjalankan program kerjanya dalam "Program Dukungan Manajemen dan Pelaksanaan Tugas Teknis Lainnya Kementerian Agama”. Meskipun sudah sangat efektif harus meningkatkan kinerjanya. Karena efektivitas Kantor Wilayah Kementerian Agama Provinsi Sulawesi Utara akan meningkat apabila manajemen dan pelaksana tugas akhir meningkat

Hal ini berarti realisasi pendapatan Kantor Wilayah Kementerian Agama Provinsi Sulawesi Utara telah mencapai/melebihi anggaran pendapatan yang ditetapkan. Kantor Wilayah Kementerian Agama Provinsi Sulawesi Utara tidak hanya mementingkan segi keuangannya saja tetapi juga masyarakat dengan melakukan program dukungan manajemen dan tugas teknis lainnya serta melaksanakan dan mendukung kebijaksanaan dan program pemerintah di bidang ekonomi dan pembangunan nasional, khususnya di bidang keagamaan. 


\section{KESIMPULAN DAN SARAN}

\subsection{Kesimpulan}

Berdasarkan hasil penelitian maka dapat dibuat kesimpulan sebagai berikut:

1. Rasio ekonomis menunjukkan hasil kurang dari $90 \%$ yang berarti cukup ekonomis dalam standar value for money. Dengan demikian Kantor Wilayah Kementerian Agama Provinsi Sulawesi Utara ekonomis dalam pemanfaatan anggaran belanjanya.

2. Rasio efisiensi menunjukan hasil kurang dari $100 \%$ yang berarti kurang efesien dalam standar value for money. Dengan demikian Kantor Wilayah Kementerian Agama Provinsi Sulawesi Utara kurang efesien dalam pemanfaatan anggaran belanjanya.

3. Rasio efektifitas menunjukan hasil berada diatas $100 \%$ (>100\%) sehingga menunjukan Kantor Wilayah Kementerian Agama Provinsi Sulawesi Utara sangat efektif dalam pemanfaatan anggaran belanjanya, hal ini menunjukan bahwa Kantor Wilayah Kementerian Agama Provinsi Sulawesi Utara sudah berhasil dalam menjalankan program kerjanya dalam "Program Dukungan Manajemen dan Pelaksanaan Tugas Teknis Lainnya Kementerian Agama".

\subsection{Saran}

Adapun saran yang dapat diberikan adalah:

1. Kantor Wilayah Kementerian Agama Provinsi Sulawesi Utara diharapkan dapat lebih memperhatikan penggunaan anggaran belanja Negara di tahun tahun kedepan, agar tidak terjadi pemborosan dana yang melebihi dari target yang telah diberikan, dapat mengefesiensikan anggaran belanjanya dengan baik, sehingga lebih tepat dalam penggunaan dana yang diberikan oleh negara dan tidak terjadi penggunaan dana yang berlebihan untuk menjalankan program kerjanya.

2. Instansi juga diharapkan dapat meningkatkan efesiensi dalam mendukung manajemen dan pelaksana tugas teknis, sehingga dengan output yang cukup besar diharapkan dapat meningkatkan efesiensinya.

\section{DAFTAR PUSTAKA}

Halim. 2013. Akuntansi Sektor Publik Akuntansi Keuangan Daerah. Edisi Empat. Erlangga, Jakarta. Hariadi. P., Restianto, dan Bawono. 2015. Pengelola Keuangan Daerah. Salemba Empat, Jakarta.

Ikatan Akuntan Indonesia. 2017. "Aplikasi Akuntansi Dasar (sesuai dengan PSAK terkini)". Penerbit Ikatan Akuntan Indonesia.

Mahmudi. 2016. Akuntansi Sektor Publik. UII Pres. Yogyakarta.

Mardiasmo. 2012. Akuntansi Sektor Publik. Andi, Yogyakarta.

Mursyidi. 2012. Akuntansi Pemerintahan di Indonesia. PT. Refika Aditama. Bandung

Mulyadi. 2014. Sistem Perencanaan dan Pengendalian Manajemen, Edisi 2. Salemba Empat: Jakarta.

Munawir. 2010. Akuntansi Sektor Publik. Edisi IV. Yogyakarta: BPFE.

Nordiawan, Rahmawati 2012 Akuntansi Pemerintah. Salemba Empat. Jakarta.

Pontoh, W. 2013 “Akuntansi Konsep dan Aplikasi”. Penerbit Halaman Moeka, Jakarta.

Pura, Rahman. 2013. Pengantar Akuntansi I - IFRS I. Penerbit Erlangga, Jakarta.

Samsudin, 2011. Otonomi dan Manajemen Keuangan Daerah. ANDI, Yogyakarta.

Sujarweni, Wiratna. 2015. Akuntansi Sektor Publik. Pustaka Baru Press, Yogyakarta. 